\title{
Are There Global Norms and Universal Standards of Electoral Integrity and Malpractice? Comparing Public and Expert Perceptions
}

\section{Citation}

Norris, Pippa. 2012. Are There Global Norms and Universal Standards of Electoral Integrity and Malpractice? Comparing Public and Expert Perceptions. HKS Faculty Research Working Paper Series RWP12-010, John F. Kennedy School of Government, Harvard University.

\section{Published Version}

http://web.hks.harvard.edu/publications/workingpapers/citation.aspx?Publd=8305

\section{Permanent link}

http://nrs.harvard.edu/urn-3:HUL.InstRepos:8506826

\section{Terms of Use}

This article was downloaded from Harvard University's DASH repository, and is made available under the terms and conditions applicable to Other Posted Material, as set forth at http:// nrs.harvard.edu/urn-3:HUL.InstRepos:dash.current.terms-of-use\#LAA

\section{Share Your Story}

The Harvard community has made this article openly available.

Please share how this access benefits you. Submit a story.

\section{Accessibility}




\section{Are There Global Norms and Universal Standards of Electoral I ntegrity and Malpractice? Comparing Public and Expert Perceptions Faculty Research Working Paper Series}

Pippa Norris

Harvard Kennedy School

\section{March 2012}

RWP12-010

The views expressed in the HKS Faculty Research Working Paper Series are those of the author(s) and do not necessarily reflect those of the John F. Kennedy School of Government or of Harvard University. Faculty Research Working Papers have not undergone formal review and approval. Such papers are included in this series to elicit feedback and to encourage debate on important public policy challenges. Copyright belongs to the author(s). Papers may be downloaded for personal use only. 
Draft 1.0 3/16/2012 7:24 PM

\section{Are there global norms and universal standards of electoral integrity and malpractice? Comparing public and expert perceptions}

\section{Pippa Norris}

\begin{tabular}{lr}
\hline McGuire Lecturer in Comparative Politics & Professor of Government \& IR \\
Kennedy School of Government & The University of Sydney \\
Harvard University & Department of Government \& IR \\
Cambridge, MA 02138, USA & NSW, 2006 \\
Pippa Norris@Harvard.edu & Australia \\
\hline www.pippanorris.com & www.arts.sydney.edu.au \\
\hline
\end{tabular}

Abstract: When international observers criticize the quality of elections, do these expert evaluations reflect 'Western/American' values? Or are there universal global norms of electoral integrity and malpractice which are shared by ordinary people living in diverse cultures? To consider these issues, Part I of this paper unpacks the core concept of electoral integrity. Part II introduces a new battery of nine items carried for the first time in the $6^{\text {th }}$ wave of the World Values Survey (WVS) 2010-12. This battery is designed to gauge perceptions of common types of electoral integrity and malpractice. Part III describes the results of the survey. Part IV then compares mass perceptions in each country against five summary indices based on expert evaluations. The conclusion summarizes the main findings and considers their implications.

Keywords: elections, voting, democracy and democratization, fraud, corruption

Bio: Pippa Norris is the McGuire Lecturer in Comparative Politics at Harvard University and Laureate Fellow and Professor of Government and International Relations at the University of Sydney. Related publications include Cosmopolitan Communications (Cambridge 2009), Public Sentinel (World Bank 2010), and Making Democratic Governance Work (Cambridge 2012).

Word Length: 13,253 
Electoral integrity and electoral malpractice have generated a growing body of research among both the academic and policymaking communities. The burgeoning literature has started to explore many issues, focusing upon three questions: when do elections meet international standards of electoral integrity? When do they fail to do so? And what can be done to mitigate these problems? New datasets have sought to quantify and measure the quality of elections. ${ }^{1}$ Research has used techniques of electoral forensics, expert evaluations, and randomized control field-experiments to detect the distribution and analyze the causes of electoral malpractice. ${ }^{2}$ Scholars have explored the potential impact of flawed contests, notably for the persistence of autocracy, regime transitions, and processes of democratization by elections. ${ }^{3}$ Studies have also sought to evaluate the effectiveness of policy remedies designed to deal with this problem, including the monitoring role of electoral observers, strengthening the capacity of independent election management bodies, and reforming the legal framework regulating party finance and campaign media. ${ }^{4}$

Before seeking to address these issues, however, it is important to consider the comparative evidence and metrics. In particular, when international observers criticize the quality of elections, do these expert evaluations reflect 'Western/American' values? Or are there universal global norms of electoral integrity and malpractice which are shared by ordinary people living in diverse cultures? If there are indeed universal norms, then public perceptions and expert evaluations should be observed to coincide. On the other hand, if mass perceptions diverge from expert assessments, then we need to understand the reasons for these contrasts, which could reflect technical and methodological differences in measurement, or a genuine lack of consensus in the normative standards used for evaluating the quality of elections.

To consider these issues, Part I of this paper first unpacks the core concept of electoral integrity, understood here as shared international principles and standards of democratic elections which apply universally to all countries and which can occur at any stages during the electoral cycle, including the pre-electoral period, the campaign, and polling day and its aftermath. Violations of electoral integrity constitute electoral malpractices. Part // introduces a new battery of nine items carried for the first time in the $6^{\text {th }}$ wave of the World Values Survey (WVS) 2010-12. This battery is designed to gauge perceptions of common types of electoral integrity and malpractice. This survey remains in the field but the available data available allows us to compare public opinion in eight diverse nations, such as Zimbabwe, Nigeria and Ukraine, utilizing the logic of the 'most different' comparative strategy. Part III describes the survey results and Part IV then compares mass perceptions of electoral integrity in each country against several 
summary indices reflecting expert evaluations. The conclusion summarizes the main findings and considers their implications. The study demonstrates that the domestic public living in Uruguay, Estonia, and Ghana perceives relatively high standards of electoral integrity in their own country, coinciding with expert judgments. Cases where ordinary people prove more critical of flaws in electoral integrity include Nigeria, Ukraine, Kyrgyzstan, and Zimbabwe, again largely consistent with expert evaluations. The correlations between mass and expert evaluations are statistically weak, however, although this is partly the result of the small number of cases. Kazakhstan appears to be something of an outlier, however, as the public in this country reports more positive views of electoral processes than expert evaluations would lead us to suspect. Thus overall in most cases there does appear to be a shared consensus between mass and elite evaluations, supporting the argument that universal normative principles and global standards can be used to evaluate violations of electoral integrity.

\section{I: The concept and components of electoral integrity}

Challenges arising from elections have been highlighted recently by diverse events, including mass protest in Moscow following Vladamir Putin's reelection to the Presidency, by Haitian riots in Portau-Prince triggered by allegations of electoral fraud, and by deadly inter-communal violence in postelection Nigeria. Elsewhere reports suggest that many other elections are commonly marred by problems such as limits on equal ballot access for opposition parties, pro-government media bias, maladministration in electoral registers, and vote-rigging at the count. Confidence in the electoral process, popular participation, and even regime legitimacy are thought to be corroded by such practices. ${ }^{5}$ We can expect long-established democracies to be sufficiently resilient to overcome minor flaws in electoral integrity, such as Floridian 'hanging chads' during the 2000 American presidential contest and questions about mail-in ballots during the 2005 UK elections. Established democracies have accumulated deep reservoirs of regime legitimacy over successive elections. ${ }^{6}$ They have also developed robust institutional mechanisms for legal appeals and the redress of grievances. It is widely feared that in the absence of these conditions, for instance in states holding elections as part of the peace-building process, such as Afghanistan and the Democratic Republic of Congo, flawed contests may heighten the dangers of instability, violence and even civil war. ${ }^{7}$ It is therefore important to understand the nature of these challenges and what can be done to avoid these problems.

The notion of 'electoral integrity' is gaining in popular usage as an all-encompassing way to conceptualize many related problems. ${ }^{8}$ Nevertheless this complex idea remains under-theorized and several related notions present alternative ways to frame similar issues, both negative terms such as 
'electoral malpractice', 'flawed elections', 'manipulated contests', and 'electoral fraud', as well as positive, where elections are described as 'credible', 'acceptable', 'genuine', or the standard rhetoric of 'free and fair'. ${ }^{9}$ Before considering questions of measurement, therefore, is important to establish a clearer conceptualization. In this study, the core notion of 'electoral integrity' refers to agreed international principles and standards of elections, applying universally to all countries worldwide throughout the electoral cycle, including during the pre-electoral period, the campaign, and on polling day and its aftermath. Conversely, electoral malpractice refers to violations of electoral integrity. Let us unpack this understanding.

\section{(i) Agreed international standards}

The first part of this definition sees electoral integrity as contests which do not violate agreed international principles and standards of elections. This approach is therefore firmly grounded in agreements which the international community has endorsed for more than half a century, rather than resting upon arbitrary judgments or being open to the charge of applying culturally-bound ('Western' or 'American') normative values. Societies vary in their legal regulations and normative standards governing elections, for example in political finance regulations governing the use of state funds for political parties, transparency and disclosure, and contribution or spending limits. Contrasts are evident even among relatively-similar long-established European democracies, such as Germany, Sweden, Britain and France. ${ }^{10}$ It would therefore be inappropriate to adopt normative standards from any one of these societies as the legitimate basis for evaluating practices elsewhere.

Article 21(3) in the Universal Declaration of Human Rights (1948) constitutes the legal basis and the core principles legitimating international support to elections and electoral assistance. Article 21(3) specifies that "The will of the people shall be the basis of the authority of government; this will shall be expressed in periodic and genuine elections which shall be by universal and equal suffrage and shall be held by secret vote or by equivalent free voting procedures." Agreement about the general standards which should govern the conduct of elections are further specified in Article 25 of the UN International Covenant for Civil and Political Rights (ICCPR of 1966), namely: 1) periodic elections; 2) universal suffrage; 3) equal suffrage; 4) right to stand for public office; 5) right to vote; 6) secret ballot; 7) genuine elections; 8) free expression of the will of the people. ${ }^{11}$ These standards are also understood as embodying rights to self-determination, after Article 1(1) which specifies that "all peoples have the right of self-determination". Since it came into force in 1976, the Covenant creates binding legal obligations for the 167 member states which endorsed the treaty, including China, Russia, Cuba, Togo, Equatorial 
Guinea, Iran, Syria, and Tajikistan, and there are moral if not legal obligations for states which have not yet endorsed the treaty, including Singapore, Saudi Arabia, UAE, and Myanmar. ${ }^{12}$ In subsequent decades, many other human rights instruments and more detailed working standards have been hammered out by the international community and endorsed in a series of conventions and legal instruments. ${ }^{13}$ The most authoritative international standards to evaluate electoral integrity have been standardized in some detail in the practical guidelines issued to electoral observers, exemplified by the Election Observation Handbook ( $6^{\text {th }}$ edition) published by the OSCE, with standards which have been adopted in similar guidelines issued by the African Union, European Union, and Organization of American States. $^{14}$

The guidelines reflect a broad consensus within the international community about the normative principles and standards which should guide many basic aspects of electoral processes, such as the need for an independent and impartial electoral authority, equal and universal suffrage, equal opportunities for candidates and parties to run for elected offices, and rights to freedom of expression. ${ }^{15}$ These standards provide the legal mandate for electoral activities by intergovernmental organizations, including the deployment of observer missions evaluating the quality of elections, as well as the guiding framework for United Nations agencies and international NGOs when providing electoral assistance for member states. At the same time, many dimensions of elections which are generally agreed at the level of fairly abstract principles have not yet been translated into practical standards. Political finance illustrates these issues. The United Nations has established agreement about certain minimal provisions governing political finance standards, notably in the Article 7(3) in the UN Convention against Corruption adopted in 2003, which specifies the need for transparency, in accordance with domestic law, in the funding of candidates for elected public office and the funding of political parties. ${ }^{16}$ The Council of Europe has gone further on these matters, while IFES has collected global practices on disclosure, spending limits, party subsidies, and enforcement mechanisms for regulating political finance. ${ }^{17}$ The international community has not yet endorsed more detailed working standards; hence despite the importance of money in politics, it remains difficult to establish a legitimate global yardstick to evaluate financial practices.

\section{(ii) Universal standards}

The second component of this conceptualization understands the concept of electoral integrity as universally applicable, where violations of shared principles and standards have the capacity to undermine the quality of elections in every society, including in long-established democracies. 
Researchers should not simply focus upon the worst cases. Problems of electoral integrity are commonly highlighted by journalists following fraudulent contests in autocratic regimes using a variety of techniques. This includes systematic pro-government media bias and voting irregularities in Putin's Russia, draconian restrictions on opposition parties and human rights by President Nazarbayev in Kazakhstan, widespread complaints of ballot box stuffing and voter intimidation at the polls in Afghanistan, with fraud so pervasive that nearly a quarter of all votes were reportedly thrown out during the 2010 presidential contests, and violent repression of opposition forces under Mugabe's regime in Zimbabwe. The news media highlights many other cases around the world with problems of outright manipulation, exemplified by undue legal restrictions on the registration of voters, parties and candidates, unfair media campaign coverage of all contestants, and fraudulent ballots cast on polling day, as well as problems of electoral maladministration arising from incompetence, lack of capacity, or malpractice. Dramatic violations of electoral integrity attract media headlines, trigger opposition protests, and generate widespread international concern about the abuse of human rights.

But in our view challenges of electoral integrity reflect universal problems which may damage the legitimacy of contests in any country, -- in Denmark, Switzerland, and Canada -- as well as in electoral autocracies. One reason for this broader understanding is historical: issues of electoral integrity have long been of concern in Western democracies, exemplified by problems of endemic bribery and treating during nineteenth century Britain, ${ }^{18}$ progressive attempts to clean up machine politics in Tammany Hall, ${ }^{19}$ restrictions on the electoral franchise for women and the working class in Europe ${ }^{20}$ practices of voter suppression and racial discrimination in the United States, ${ }^{21}$ and the introduction of compulsory voting and the secret ballot in Australia. ${ }^{22}$ Nor are these issues simply historical curiosities in established democracies; contemporary challenges in American elections are exemplified by the notorious problem of hanging chads and faulty voting machines in Florida, the substitution of votes for dollars by super-PACs, and increasingly restrictive voter registration and identification requirements. ${ }^{23}$ Even where many minimal conditions are met, expectations of electoral integrity are not frozen in time; instead new challenges continue to arise. There is a broad consensus in principle about many of the basic nuts-and-bolts conditions required to achieve minimal standards of electoral integrity, such as the requirements of an inclusive adult franchise, a level playing field in campaign media, honest vote tabulations, and the use of secret ballots. But debate continues about the most appropriate response to complex new issues facing all democracies, including growing demands for gender equality and minority representation, the challenge and opportunities of new voting 
technologies and online balloting, and the appropriate regulatory framework governing political finance, campaign broadcast news, and paid political advertising, especially in the age of social media.

Challenges of electoral integrity can be expected to prove least damaging for legitimacy in longestablished democracies which have accumulated a deep reservoir of diffuse support for democratic principles and practices over many decades or even centuries. Many, although not all, established democracies have also gone furthest to develop independent election management bodies capable of administering contests according to professional standards. Legal channels help to resolve disputes peacefully through the courts. The consequences of any electoral irregularities can be expected to prove more corrosive of regime legitimacy, and thus potentially destabilizing, in countries lacking these conditions. Citizens living in deeply-divided societies with recent experience of deep-rooted conflict are expected to display minimal trust and confidence in state authorities, legal institutions, and electoral processes, and to have low reservoirs of social trust and tolerance. The potential dangers of electoral violations are also expected to be heightened by winner-take-all contests, such as the 2011 presidential elections in the Democratic Republic of Congo in 2011 and the 2010 presidential contests in Afghanistan. In this context, popular unrest and violence may be triggered or reignited where losing parties seize on even minor technical infringements, such as the lack of official ballot papers in a few polling stations or some clerical errors in electoral registration lists, to challenge the legitimacy of the outcome. A dramatic illustration of how malpractices can destabilize a state concerns the Kenyan presidential elections in December 2007. President Mwai Kibaki, leader of the Party of National Unity, was announced to have won, but international observers noted major electoral irregularities and the opposition leader, Raila Odinga, refused to accept the result, accusing the incumbent party of vote rigging. The dispute triggering days of urban riots, leading to an estimated 1,300 deaths and 250,000 displaced persons. The conflict was only settled eventually by a brokered power-sharing deal among the two main protagonists, but the communal violence may well have undermined public confidence in the electoral process and in the coalition government. Mansfield and Snyder warn that elections held after peace-settlements in fragile states have the capacity to trigger further conflict, rather than strengthening the peace process. ${ }^{24}$

For all these reasons, concern about electoral integrity has become of increasing priority for the international community during the third wave era of democratization. Today only a handful of states continue to be ruled by absolute monarchies and emirs, such as Saudi Arabia, Qatar, Brunei, and UAE, without even the fig-leaf of direct elections for the lower house of national parliaments. ${ }^{25}$ The growth in the use of direct elections worldwide has been accompanied by increasing concern about the 
unevenness of their quality. The international community has responded to these developments with two types of initiatives. First many agencies have sought to expand the capacity and professional standards of independent election management bodies. This includes work by the International Institute for Democracy and Electoral Assistance (IDEA), the International Foundation for Election Systems (IFES), the National Democratic Institute for International Affairs (NDI), and United Nations Development Programme (UNDP), in partnership with regional organizations such as the European Union, bilateral partners, and local stakeholders. ${ }^{26}$ Secondly, many agencies have also sought to strengthen the transparency of election procedures and to monitor the implementation of internationally-agreed standards and principles. In particular, thousands of international and domestic observers are deployed in election missions, most commonly deployed by regional organizations including the Organization of Social and Economic Cooperation (OSCE), the African Union (AU), the European Union (EU), and the Organization of American States (OAS). ${ }^{27}$ Local election watch and media watch NGOs supplement these activities, along with attempts to strengthen the independent media and civil society organizations. The international community's work on electoral integrity is perhaps the most visible part of a much larger set of initiatives designed to strengthen democratic governance - although not necessarily the area receiving the most investment in recent decades. The international community's efforts to assist states seeking to strengthen democratic governance, although remaining a relatively modest amount of overall development aid, have expanded to an estimated US\$5 billion annually. ${ }^{28}$ During the last decade the UNDP alone has invested from US\$1.2 to $\$ 1.5$ billion every year to programs strengthening democratic governance in 130 developing countries worldwide, out of a total budget of around $\$ 5 \mathrm{~m}$. Recent initiatives by the UNDP include launching the Global Programme for Electoral Cycle Support (GPEC) in 2009, designed to help countries improve their electoral laws, processes and institutions and to enhance the participation of women in electoral processes. ${ }^{29}$

\section{(iii) The cycle of electoral integrity}

The international community has also moved towards understanding that electoral assistance and electoral observation should not be focused purely upon election-day, or even on the short-term period of the official campaign. Instead, elections should be seen as a sequential process or cycle involving a long series of steps. As the ACE project suggests, the cycle involves all stages in the process of elections: "from the design and drafting of legislation, the recruitment and training of electoral staff, electoral planning, voter registration, the registration of political parties, the nomination of parties and candidates, the electoral campaign, polling, counting, the tabulation of results, the declaration of 
results, the resolution of electoral disputes, reporting, auditing and archiving. After the end of one electoral process, it is desirable for work on the next to begin: the whole process can be described as the electoral cycle." ${ }^{30}$

The most visible types of electoral malpractice involve illegal acts on polling-day or immediately afterwards, such as vote tabulation fraud, carousel voting, or ballot stuffing. In fact, however, problems can occur at any stage in the electoral cycle. As Sarah Birch emphasizes, the more technical and subtle forms of malpractice, through the strategic manipulation of the legal framework governing elections, occur well in advance of polling day, and these may also be the least visible to observers. ${ }^{31}$ This can include designing overly restrictive or cumbersome nomination requirements for gaining ballot access, patronage appointments eroding the independence of broadcasting regulatory bodies and the management of state-controlled television channels, the partisan gerrymandering of constituency boundaries to favor incumbents, or the passage of restrictive voter registration laws, discouraging turnout. These types of legal strategies are also less likely to incur critical media headlines, international condemnation, and domestic protests than more overt forms of intimidation and corruption at the ballot box on polling day. The idea of an electoral cycle is also similar to the way that Andreas Schedler understands the notion, as he suggests that problems of democratic elections involve a 'menu of manipulation' which ranges sequentially from restrictions on the range of electoral offices through the formation and expression of preferences to the consequences of voting choices. ${ }^{32}$ If conceived in this way, breaking any single link in the chain is capable of undermining the democratic quality of elections. Electoral malpractices may also arise from intentional restrictions on democratic human rights, such as where autocratic rules seek to manipulate electoral rules unfairly to limit opposition, but they may also be caused by maladministration and lack of governance capacity, such as administrative errors in registration rolls, or the state's lack of capacity to maintain security.

Therefore as conceptualized and defined by this study, to recapitulate, electoral integrity reflects elections held in accordance with internationally-agreed standards and principles. Electoral malpractice involves practices which violate agreed international standards and principles, which may potentially occur in any country around the world, and which may also involve any stage in the long sequential cycle of electoral processes, including the pre-electoral period, the campaign, and polling day and its aftermath. 


\section{II: Measuring the concepts of electoral integrity and malpractice}

Given this conceptualization, it is important to establish valid metrics. Descriptive narrative case studies provide rich insights into how specific practices violate agreed standards of elections and deepen our understanding of how violations of electoral processes work in particular countries and regions. Cases are also invaluable for building more general causal theories. ${ }^{33}$ Nevertheless it remains hazardous to draw broader lessons from individual cases; for example, Florida in 2000 was not Minnesota, Georgia, or Oregon. Kenya is not the DRC. Afghanistan is not Iraq. And so on. By contrast, systematic quantitative measures of electoral integrity are invaluable to monitor, document and analyze violations of international standards. They are essential to generalize about the causes and consequences of electoral integrity worldwide. And they can serve as benchmarks for evaluating the success of policy interventions.

Any measures of electoral integrity should meet acceptable standards for scholars and practitioners, striking a careful balance across several competing criteria. ${ }^{34}$ Ideally indicators should be conceptually valid, meaning that the empirical data and aggregate measures relate logically and consistently to the overarching notion which is being operationalized. Transparent methods should be used for gathering data and then constructing summary indices, so that evidence can be subject to scrutiny and replication tests by independent scholars or observers, using consistent scientific methods and standard techniques. Measures should also be universally generalizable, rather than idiosyncratic, so that they can be applied to monitor elections held in diverse global cultural regions, under different types of regimes, and during alternative time-periods. To have any practical impact, indices of electoral integrity should ideally also be politically legitimate, meaning that they are regarded as authoritative and usable by the international community and domestic stakeholders. They also need to be measured with sufficient precision to allow analysts to identify the source and gravity of any violations of electoral integrity, and thus determine suitable remedies, rather than being so abstract and general that they prove too blunt for accurate diagnosis.

[Tables 1 and 2 about here]

As summarized in Tables 1 and 2, both expert evaluations and public opinion surveys have been used to gauge various components of the quality of elections. Typically survey respondents are asked about their perceptions of violations of electoral integrity, or their reported experiences, as well as their broader attitudes towards political institutions and democratic governance, such as trust in electoral authorities and confidence in the responsiveness of elected officials. Social surveys use a standardized 
questionnaire to gather data from a representative sample of the adult population within each nation. Inferences are then drawn about the general population within each country. For example campaign tracking and post-election national surveys of public opinion have been used by the International Foundation for Electoral Systems (IFES) to monitor citizens' perceptions of democracy, opinions about elections, and assessments of the overall situation in their country, such as in Indonesia, Kosovo and Ukraine. These are invaluable for within country assessments, although the lack of a standardized questionnaire in the IFES surveys hinders their use for cross-national analysis.

Surveys vary when measuring how people see the quality of elections and most have used one or two simple proxy or summary measures (see Table 1), such as asking respondents about their perceptions of the honesty or fairness of the contests. For example, the 2005 Gallup International surveyed perceptions of 'free and fair' elections among citizens in 65 countries around the globe, reporting that opinion was equally divided between those who believed that elections in their own country are free and fair (47\%) and those who do not (48\%). ${ }^{35}$ In the same survey, only one third of the public thought that their own country was governed by the 'will of the people'. Thus general concern about the quality of elections appears to be widespread among the general public but such evidence does not establish the cause of any perceived problem, such as whether those expressing negative judgments were most critical of the fairness of electoral officials, the role of the news media or fraud at the ballot box. Gallup International also unfortunately amended the question included in their annual international survey to gauge perceptions of electoral integrity, preventing comparison of a consistent time-series.

Where mass and expert assessments diverge, there are several reasons why mass surveys are to be preferred. Firstly, and perhaps most importantly, representative surveys allow evaluations to be disaggregated below the national level, for example to analyze whether perceptions about the quality of elections vary, as might be expected, among winners and losers of the contest, as well as among young and old, rich and poor, college graduates and illiterate populations with minimal schooling, urban and rural populations, women and men, those heavily reliant for news from state-controlled TV and those tuned into social media, and so on. In addition, social surveys monitor the perceived concerns or actual experience of elections among a representative sample of the public living within each country. Inferences are drawn about public opinion in each country, based on estimates of the margin of error and probability. By contrast, expert assessments reply upon more ad-hoc sources as there is no sampling frame of 'experts' on electoral integrity, such as electoral observers, government officials, journalists, 
and scholars. Observer reports of elections present a systematically skewed sample of cases. Social surveys also allow citizens to evaluate the quality of elections within their own country. As such, these are regarded as more legitimate than evaluations of electoral integrity based on judgments by experts especially international observers. Democratic principles suggest that ultimately the judgment of the domestic publics within each country should be regarded as the most appropriate arbitrator of electoral standards: who, after all, has deeper awareness of problems of intimidation, bribery, and threats in polling places? Public perceptions of electoral integrity also matter, irrespective of whether these perceptions are based on accurate, rational and informed judgments, for example perceptions about stolen or corrupt elections can generate political protests or popular uprisings.

Despite these potential advantages, social surveys have limits and where mass and expert evaluations diverge, there are several possible reasons why evidence from expert assessments may be preferred. In particular, the meaningfulness and reliability of the responses can be questioned when surveys are fielded in autocracies which lack widespread freedom of information and expression, where citizens may have good reason to be wary about voicing open criticism of government officials in public. It is difficult to establish whether survey replies are 'self-censored', out of fear of retribution. Citizens may take their cues from leaders; where losing parties claim widespread electoral fraud, their followers may well believe them. Moreover even in more open societies, major violations of elections can also occur by manipulating technical regulation of ballot access and registration requirements well before the start of the official campaign, and citizens may not be aware of such practices. Public perceptions of electoral integrity can also be expected to be learnt over time, with judgments becoming more informed through repeated experience. As a result, people living in countries with little or no previous history of democratic contests, and with restricted access to information about elections held abroad, may lack appropriate cues to frame their expectations and evaluations. For all these reasons, it is important to compare the results of the expert evaluations and public perceptions to check whether these coincide and, if they diverge, to seek to understand the reasons for different judgments.

\section{The WVS perception of electoral integrity and malpractice scales}

Building upon the mass survey approach, this study presents the preliminary results of two new measures, the Perception of Electoral Integrity and Electoral Malpractice scales, based on a multidimensional battery of nine items contained in the $6^{\text {th }}$ wave of the World Values Survey (WVS). Fieldwork for the $6^{\text {th }}$ wave continues from 2010 to 2012, as this survey currently remains in progress, but the initial results which are already available can be analyzed to compare public opinion in eight 
diverse countries. Once fieldwork is completed, the final results of the $6^{\text {th }}$ wave WVS will expand the analysis to many other societies.

\section{Comparative framework and case selection}

The comparative framework in the eight cases selected for analysis in this study includes diverse types of regimes as well as countries in sub-Saharan Africa, post-communist Europe, and Latin America. This includes two electoral autocracies holding contests which are seriously flawed for different reasons, as exemplified by violent intimidation and state repression of opposition activists in Zimbabwe and noncompetitive contests in Kazakhstan, where President Nursultan Nazarbayev won an estimated 95.5\% of the vote. Elections are also analyzed where there are less serious violations reported, including in Nigeria, experiencing post-election inter-communal violence, Ukraine, where opposition parties alleged electoral fraud, and Kyrgyzstan, with administrative irregularities in recent contests. Public perceptions are also compared with three liberal democracies which observers agree display higher standard of electoral integrity, functioning as a control, including Ghana, Estonia, and Uruguay. Table 3 provides background information about the election to the lower house of the national legislature or the presidential election which immediately prior to the date of the survey fieldwork in each country.

\section{[Table 3 about here]}

\section{Question design, measurement and aggregation}

When constructing scales, it is important that they meet the requirements of measurement validity, reflecting the underlying concepts. The items which were selected for the survey reflect widelyaccepted international principles and standards, such as the requirement that votes should be fairly tabulated, the freedom of opposition candidates to run for elected office should not be restricted, and voters should not experience intimidation or violence at the polling station. These basic and minimal requirements are firmly grounded in international conventions on universal human rights. Questions where international agreement has not yet been established were avoided, such as asking whether there should be limits on campaign spending or contributions.

The electoral cycle approach adopted in this study assumes that the most overt techniques which are intentionally designed to distort the genuine will of the people arise from ballot stuffing, vote rigging and fraud on polling day and its aftermath. But many more subtle and legal techniques which also violate international standards are often employed well away from the public spotlight to limit party and candidate competition before a single ballot is cast, during the pre-election and campaigns 
periods, such as through overly-restrictive voter registration processes, ballot access requirements, and electoral thresholds. The items were therefore designed to reflect different stages in the electoral cycle, as shown in Figure 1, not simply problems occurring on polling day.

The conceptualization also assumes that no country is wholly immune from problems of electoral administration and challenges of human rights. To reflect this understanding, the questions reflect universal issues which can potentially undermine electoral integrity in every country. Thus although electoral violence and bribery of voters are exceptional today in long-established democracies, the fairness of election officials and pro-government bias in TV news are common challenges for the quality of elections in every country. To monitor public attitudes, the $6^{\text {th }}$ wave of the WVS asked respondents the following questions:"In your view, how often do the following things occur in this country's elections?

\author{
V228A. Votes are counted fairly \\ V228B. Opposition candidates are prevented from running \\ V228C. TV news favors the governing party \\ V228D. Voters are bribed \\ V228E. Journalists provide fair coverage of elections \\ V228F. Election officials are fair \\ V228G. Rich people buy elections \\ $\mathrm{V} 228 \mathrm{H}$. Voters are threatened with violence at the polls \\ V228I. Voters are offered a genuine choice in the elections
}

Respondents were asked to reply on a 4-point scale from 'very often' to 'not at all often'. These items were designed to reflect common issues in elections, described in everyday language, avoiding more technical matters which may be poorly understood, such as attitudes towards specific laws, regulations or electoral systems. The questions also ask respondents about their perceptions, rather than their direct experience. One reason is that respondents may be reluctant to acknowledge first-hand involvement in some problems, such as bribery or violence, due to fear of retribution, legal penalties, or moral norms. The significance and severity of any violations for electoral integrity also varies across the items, as does their meaning and interpretation in different contexts, for example in judging what counts as 'genuine choice' or pro-government bias in TV news. The list was ordered to intersperse positive questions about integrity and negative questions about malpractice, to encourage respondents to consider each item separately. The questions were also framed to capture perceptions of 'this country's elections' in general, at whatever level, rather than to gauge reactions to a specific contest for local, legislative or executive office. Clearly controversial results in recent high-profile contests may have 
been at the forefront of respondents' minds when answering, but we also sought to monitor perceptions of the usual quality of elections in each country over successive contests.

[Table 4 about here]

Careful measurement is also important. Indices of electoral integrity are often coded using binary categories or ordinal-level measures using limited scales, denoting summary 'pass/fail' judgments. But continuous or internal-level measures are arguably preferable, providing finer-grained responses, as perceived problems arise with different degrees of severity. Responses for each of the survey item were gauged on a four-point ordinal scale, ranging from 'not at all often' to 'very often'. Principal Component Factor Analysis with varimax rotation, shown in Table 4, confirmed that the items fell into two distinct dimensions, measuring positive and negative evaluations. The individual items can be examined separately to identify specific problems. For an overview, the Perceptions of Electoral Integrity scale and the Perceptions of Electoral Malpractice scale were both constructed by summing the separate positive and negative item responses, each with equal weight, and standardizing the scale to 100-points, for ease of comparison with the expert indices. The results in Table 5 present the proportion of respondents in each country who responded 'very' or 'fairly' often to the battery of items.

\section{III: Public perceptions of electoral integrity and malpractice}

The results of the WVS survey are summarized in Figure 2 and they are compared in more detail

across all items in Table 5. The scatterplot suggests some clear contrasts among the countries, with many of the liberal democracies clustered in the bottom-right quadrant, with low perceptions of electoral malpractice and high perceptions of electoral integrity. But Kazakhstan is also an outlier positioned near this cluster. By contrast, the autocratic regimes are located in the top-left quadrant, with low perceptions of integrity and high perceptions of malpractice. Let us describe the results in more detail by the type of regime and the context of each country's political background and electoral experiences.

[Figure 2 about here]

\section{Liberal democracies: Uruguay, Estonia and Ghana}

Of these cases, Uruguay and Estonia displayed the most positive public evaluations of electoral integrity. In these countries, around three-quarters of the public expressed positive evaluations of the fairness of their elections. Uruguay and Estonia were also rated low on electoral malpractices by their citizens, without any problems of electoral violence and with a fairly even playing field. Uruguay's 
transition to democracy began in the mid-1980s, when the army and political leaders agreed to return to constitutional government and release political prisoners. In Estonia the transition process started in 1991, with the collapse of the Soviet Union; since emerging as a stable parliamentary democracy, achieving the highest per capita GDP among the former Soviet republics and becoming a leader in information technology. Today both countries are classified by Freedom House as liberal democracies which have enjoyed high levels of political rights and civil liberties for many years, and these countries have experienced a series of peaceful elections. ${ }^{36}$

[Table 5 about here]

Among West African nations, Ghana is also widely regarded today as one of the most successful contemporary democracies on the continent. During the late-1980s the country began to move towards economic stability and the transition towards democracy. In April 1992, a constitution allowing a multiparty system was approved in a referendum, ushering in a sustained period of democracy under the fourth republic. Since then, Ghana has experienced periodic multiparty contests which international observers have regarded as free and fair. ${ }^{37}$ In the presidential elections in December 2008, the results which were extremely close, with less than $0.5 \%$ of the vote separating the top two presidential candidates, but nevertheless the outcome was largely peaceful. The European Union was among a host of institutions observing these contests, including the Carter Centre, ECOWAS, African Union, and over 4000 representatives from the Coalition of Domestic Observers (CODEO). The EU reported that the Electoral Commission who administered the contests proved impartial, professional, and independent, ensuring the transparency of the process. Electoral observers and party agents were able to observe all stages of polling, vote counting, and aggregation. There were clear legal channels for complaints and appeals challenging the results and the Commission worked to ensure conciliation and acceptance of the process among the major stakeholders. There were some minor administrative irregularities experienced on polling day, but the Electoral Commission apologized for these and sought to rectify the situation. Disputes followed the second round of presidential voting, and tensions rose in the tight contest with some slight delays in announcing the vote, but these were eventually resolved without conflict. The perceptions of electoral integrity items show that most people in Ghana believe that their elections are fair, and that there is free competition for opposition candidates, but nevertheless they remain more critical of voter bribery and suspicious of the power of rich people to buy elections.

Autocratic regimes: Nigeria, Ukraine, Kyrgyzstan, Kazakhstan and Zimbabwe 
By contrast, recent contests in the other countries under comparison highlight more serious problems of electoral malpractice. In Nigeria, the April 2001 Presidential and parliamentary elections were deemed credible and largely successful by African Union observers, with high turnout and with praise for the role of the Independent National Electoral Commission. After voting ended, the public could observe the vote count in each polling station. President Goodluck Johnson from the governing People's Democratic Party (PDP) was declared the winner with $57 \%$ of the vote, avoiding the need for a run-off second ballot. Yet his victory was quickly followed by major outbreaks of post-election intercommunal violence between Muslim and Christian communities in several northern cities. Thousands of people have died over the past few years in communal rivalry and separatist aspirations have been growing, with the north lagging behind in education, infrastructure, and poverty. The results of the survey show that In Nigeria a bare majority thought that elections were often fair, especially the role of journalists. But none the less Nigerians proved more critical of the role of money in politics and voter intimidation at the polls.

Some of the worst problems of electoral malpractice, violating international standards, are reported by observers in Kazakhstan and Zimbabwe. In Kazakhstan, President Nursultan Nazarbayev was reelected in 2011 following a contest which the Organisation for Security and Co-operation in Europe (OSCE) observer mission reported was in a non-competitive environment, given the absence of opposition candidates and excessive restrictions on the right to be elected, freedom of assembly, and freedom of expression, although technically well-administered. Kazakhstan's Central Election Commission claimed Nazarbayev won 95.5 percent of the vote, with a turnout of $89.5 \%$.

In Zimbabwe, during the first round presidential elections in March 2008, the opposition leader, Morgan Tsvangirai (MDC) gained more votes than President Robert Mugabe (ZANU-PF), although officials said that no candidate achieved the $50 \%$ required for victory. A second round run-off election was held in June, but Mr Tsvangirai subsequently withdrew following numerous reports of systematic attacks against MDC activists, including killings and abductions. Citizens were coerced to vote in the onecandidate second ballot. The Secretary General of the UN criticized the violence and intimidation surrounding the elections. The violence only ceased following a brokered and uneasy power-sharing agreement between the major leaders.

In Kyrgystan, following the 2011 presidential elections, the OSCE observer mission report noted that there were problems in the integrity of voting, counting and tabulation with cases of ballot box stuffing, multiple and family voting, vote-buying, and bussing of voters. The survey found that citizens in 
this country were particularly critical of electoral officials, and they believe that there was fairly widespread malpractice, notably bias in TV news and corruption.

Nevertheless it is striking that in fact public perceptions of the fairness of elections were fairly similar in most of the autocracies (see Figure 2), with Ukrainians the most critical out of those surveyed. The OSCE observer mission reported that the 2010 Ukrainian elections largely met international standards of democratic elections, the process was transparent, and voters were offered a genuine choice of candidates, although the legal framework was deficient and unsubstantiated allegations of electoral fraud negatively affected the election atmosphere and voter confidence in the process. The opposition leader, Tymoshenko, alleged "large-scale fraud" in the country's first Presidential vote since the 2004 Orange Revolution. The coalition of Western-leaning political factions in Ukraine's Parliament disintegrated. It appears that these accusations were widely believed since the survey showed exceptionally poor perceptions of electoral malpractices in Ukraine, largely through corruption rather than violence.

\section{IV: Comparing public and expert evaluation indices}

The contextual reading of observer reports there suggests some clear similarities in how missions assess the quality of recent elections and how citizens see them, although there are also some contrasts in these assessments. But is there more systematic evidence that mass and elite judgments coincide? The results of public perceptions from the WVS can be compared with five alternative measures constructed from coding expert evaluations of electoral integrity and malpractice (see Table 2). This includes (i) Sarah Birch's Index of Electoral Malpractice, ${ }^{38}$ (ii) Susan Hyde and Nikolay Marinov's coding of National Elections across Democracy and Autocracy (NELDA), ${ }^{39}$ (iii) CIRI's Human Rights Data Project measuring 'self-determination' rights, ${ }^{40}$ (iv) Judith Kelley's Quality of Elections Data (QED), ${ }^{41}$ (v) Freedom House's classification of 'electoral democracies' ${ }^{42}$

[Table 2 about here]

\section{(i) Index of Electoral Malpractice}

The Electoral Malpractice dataset, developed by Sarah Birch, covers elections in 61 states from 1997 to 2007. For evidence, the project recoded information derived from election observer reports published by regional organizations such as the OSCE, AU and OAS. Codes are checked for inter-coder reliability. The notion of 'electoral malpractice' is divided into three subcategories according to the legal framework, campaign practices, and electoral administration. ${ }^{43}$ This Index therefore seeks to be 
comprehensive, covering all stages in the electoral cycle. Electoral malpractice is measured using 14 separate items which reflect these categories, coding information about each election contained in the observer reports on 5-point scales, such as the process of voter registration, vote counting, and media coverage. Scores in each election are then aggregated, with equal weighting given to each item, to construct the overall summary Index of Electoral Malpractice. The index used in this study followed similar practices, summing all 14 items and creating a standardized 100-point score, for ease of interpretation and comparison.

Evidence derived from observer mission reports provides a rich source of information but nevertheless reliance upon this single source may generate a systematic bias, as only certain countries allow and attract observer missions. Needs assessment exercises prior to deployment by international agencies determine whether conditions are thought appropriate for missions. Hence the OSCE guidelines recommend not sending observers to places with severe security threats. Moreover not all countries allow international observers to visit, and powerful autocratic states with the most blatant disregard for human rights are most likely to prevent any mission. On the other hand, given limited budgets and personnel, observer missions are also not sent to countries where there are believed to be few or no major problems of electoral integrity. Thus both 'floor' and 'ceiling' effects determine the types of contests included in observer reports, and how far we can generalize from these cases. 'Experts' employed as international observers, as well as US Department of State officials and Western journalists, may also employ evaluative standards drawing upon their own experiences but which diverge sharply from the perceptions of ordinary citizens living within each country.

\section{(ii) NELDA}

An alternative expert-based measure concerns Susan Hyde and Nikolay Marinov's coding of National Elections Across Democracy and Autocracy (NELDA). ${ }^{44}$ This project uses an extensive list of secondary sources, including academic election handbooks, online resources, news media, and official reports. It thereby allows comprehensive analysis of countries worldwide, with the most recent version extending coverage to all national legislative and presidential election events in independent nationstates with populations over half a million during the period from 1945 to 2010. The NELDA project codes multiple components of electoral integrity, and it focuses upon measures of electoral competition. Building upon the dichotomous classification of democracies and autocracies developed by Alvarez, Cheibub, Limogi and Przeworski (ACLP), Hyde and Marinov seek to measure the degree of competitive elections. ${ }^{45}$ This notion is measured by three criteria: (i) whether opposition is allowed; (ii) 
whether more than one party is legal; and (iii) whether there is a choice of candidates on the ballot. The NELDA dataset seeks to code the conduct of national legislative and presidential election events according to a series of standardized and transparent procedures. The resulting measure of electoral competition is invaluable for 'précising' the regime classifications based on the ACLP understanding, and thus for categorizing types of regimes, for analyzing regime transitions, and for understanding processes of democratization. Arguably, however, electoral competition provides only a minimal indicator of the broader concept of electoral integrity, as it excludes many important conditions which international standards seek to monitor. Even if major opposition parties and candidates can run, the legal framework, campaign media regulations, and party funding rules can still be heavily skewed towards incumbents. Therefore to create a broader index of electoral malpractice, a standardized scale was constructed from a dozen items relevant to the cycle of electoral integrity contained in the NELDA dataset (see the Technical Appendix for details). Mean scores were summarized for each nation from 2005-2010.

\section{(iii) CIRI Self-determination Rights}

The third expert-based classification used for comparison is the CIRI dataset developed by Cingranelli and Richards to measure human rights. Amongst other aspects, the project seeks to measure the concept of 'rights to self-determination', based on recoding information from US State Department annual country reports into a three point ordinal scale, based on the extent to which citizens enjoy 'freedom of political choice' and 'the right to change the laws and officials which govern them through free and fair elections'. The CIRI dataset monitors a broad range of human rights in 195 countries from 1980 to 2006, allowing electoral self-determination rights to be compared with other dimensions. ${ }^{46}$ Nevertheless it remains unclear how 'freedom of political choice' and 'free and fair elections' are interpreted and coded in practice, given the multiple aspects of elections which can determine these outcomes. If a country is rated poorly by $\mathrm{CIRI}$, is the problem one of legal restrictions of opposition party registration or ballot access, lack of freedom of the press, or vote rigging in polling stations? From the CIRI coding, it is not possible to determine the precise cause of any practices undermining electoral malpractice. Moreover reliance upon the US State Department official reports as the source of evidence raises questions about the legitimacy of the dataset, as the estimates remain open to the charge of cultural or political bias. The US State Department is not an independent and impartial judge and official assessments of human rights are likely to be colored by American foreign policy interests. 


\section{(iv) Quality of Elections Data (QED)}

The fourth expert-based dataset used for comparison in the Quality of Elections Data (QED) developed by Judith Kelley. Like CIRI, this also draws upon the US State Department official reports as the source of evidence, comparing elections from 1978 to 2004. In SA1 the dataset summarizes the overall election quality of any contest using an ordinal scale according to whether the US State Department reported that a contest was acceptable (0), ambiguous (1), or unacceptable (2) in representing the will of the people. In SA2 the extent of the problem is coded, ranging from good (0), low (1), moderate (2) and high (3). Further items monitor many specific components of each election, also based recoding the official state department reports, including the quality of the legal framework, campaign environment, electoral administrative capacity, election violence, and polling day fraud. The two summary items measuring the overall election quality (SA1) and the extent of problems (SA2) were added, reversed, and standardized in a 100-point Quality of Elections scale (see the Technical Appendix). As with the CIRI dataset, the US state department reports can be expected to be influenced by American foreign policy priorities, rather than independent or scholarly concerns, however, so the legitimacy of this resource remains to be determined.

\section{(v) Freedom House's classification of electoral democracies}

Lastly, the Freedom House general methodology monitoring political rights and civil liberties is widely familiar to most scholars. The organization rates country worldwide on an annual basis using a standard instrument with evaluations gathered from expert assessments. A binary (0/1) classification is used by Freedom House to classify a country as an 'electoral democracy' if it scores 7 points or more in total (out of a possible 12) for three political rights subcategory questions on electoral process: 1 . Is the head of government or other chief national authority elected through free and fair elections? 2 . Are the national legislative representatives elected through free and fair elections? 3. Are the electoral laws and framework fair? Electoral Democracies also need to score as a total of 20 points or more (out of a possible 40) for all ten political rights questions monitored by this organization. All other countries are deemed to be autocratic. Freedom House provides the broadest geographic coverage worldwide, including micro-states and even dependent territories, with the annual ratings of electoral democracies published from 1989 to 2011. Since there is a well-known tendency for smaller countries to be more democratic, it is important not to exclude them from the analysis. ${ }^{47}$

[Table 6 and 7 about here] 
The results of the comparison of the mass and elite evaluation scores are listed for each nation in Table 6 and the correlations are presented in Table 7. Clearly with only eight national cases, it would not be expected that the results could necessarily prove statistically significant at the conventional $0.5 \%$ level. What the correlations reveal, however, is that there is a remarkably strong and statistically significant correlation across all the expert indices. Despite their different construction, measurement, conceptualization, and sources of information, it appears that there is a broad consensus in the NELDA, QED, IEM, CIRI and Freedom House measures. These could all still be suffering from a systematic bias, for example through using similar 'Western' sources, such as election observer reports, and through the 'hall of mirrors' effect which arises from publishing indices. Nevertheless it appears that the indices share a remarkably similar evaluation of the quality of elections in the countries under comparison. The results also suggest that despite debates about conceptualization and measurement, some of the simpler measures, such as the CIRI self-determination rights index or Freedom House's simple binary classification of electoral democracies, may serve as accurate proxies for more elaborately constructed indices of electoral integrity and malpractice.

What the analysis also shows, however, is that the survey-based perceptions of electoral integrity and electoral malpractice scales are negatively correlated with each other, as expected. The perception of electoral integrity scale from the WVS is correlated significantly with the QED Quality of Elections scale $(R=.721 \mathrm{p.04})$, and also strongly related to the NELDA and IEM scales (although not reaching statistical significance at the conventional 0.05 level). The WVS perception of electoral malpractice scale is correlated more weakly with the expert indices and again the relationships fail to reach statistical significance. It remains to be seen whether the eventual addition of more cases will change this interpretation.

\section{V: Conclusions and discussion}

Concern about electoral malpractice has risen on the policy agenda in the international community and among many democratic stakeholders due to the important consequences thought to flow from this phenomenon; malpractice is thought to weaken the quality of democratic governance, through distorting electoral competition, potentially undermining feelings of political trust and legitimacy, dampening voter turnout and participation, and, in the most extreme cases, stoking regime instability, violence, and even civil war. But under what conditions do elections meet international standards of electoral integrity? Why do they fail to do so? What consequences flow from lack of integrity? And what strategies follow for those seeking to strengthen democratic governance? 
This study has added to the research literature by comparing mass and elite evaluations to see whether there are shared norms about the principles and standards which should operate in elections, or whether expert assessments differ sharply from the publics living within each country. The results presented here present just the preliminary analysis of the available data and further research will expand the comparative framework and extend our knowledge base. Three key findings emerge from the study.

First, public perceptions of electoral integrity and electoral malpractice do often reflect the published reports of electoral observer missions in each country, with the public distinguishing many similar problems and challenges as the experts. There is not a perfect match, however, in every case. This suggests that using mass surveys to evaluate the quality of elections would be a useful supplementary method to the standard monitoring provided by international observer missions, reinforcing the voice of the public, as IFES and some related development agencies have already recognized. Secondly, there is a remarkably strong consensus among the alternative quantitative expert indices measuring electoral integrity and electoral malpractice. Even though these are constructed independently by each study, using different concepts, sources, time-periods, and measures, nevertheless in practice the results in the cases under comparison seem to reflect shared normative standards. This increases confidence in the scientific reliability and the robustness of the results of using any of these expert measures. Moreover the simpler measures which are well established in the research literature, such as CIRI's classification of self-determination rights, are strongly correlated with the results of more ambitious and detailed coding schemes. Further research will also extend the comparisons to consider correlations among all countries and time-periods included in these expert indices. Finally, when it comes to normative standards of fairness, the general public living in each country often seems to share similar evaluations of the integrity of elections with the independent experts. There seems to be a weaker link between public perceptions of electoral malpractice and the expert indices, but it remains to be tested in future research whether this is simply due to the limited number of cases under comparison or to other reasons. Overall the study does lend support to the thesis that global norms are shaping a shared consensus about the international principles and standards which should operate to uphold human rights and strengthen electoral integrity in countries around the world. 
Table 1: Public perceptions of electoral integrity in cross-national surveys

\begin{tabular}{|c|c|c|c|c|c|c|}
\hline Project & PI & Period & \begin{tabular}{c|} 
N. \\
nations
\end{tabular} & N. elections & Data sources & Measures \\
\hline $\begin{array}{l}\text { World Values Survey } \\
6^{\text {th }} \text { Wave }\end{array}$ & $\begin{array}{l}\text { Ronald } \\
\text { Inglehart }\end{array}$ & $\begin{array}{l}2010- \\
2012\end{array}$ & c. 60 & c. 60 & $\begin{array}{l}\text { National surveys of } \\
\text { the adult population }\end{array}$ & $\begin{array}{l}\text { Electoral integrity and electoral malpractice are monitored using a 9- } \\
\text { item battery of questions where responses to each item are coded on a } \\
\text { scale from } 1 \text { 'Very often' to } 4 \text { 'Not at all often'. "In your view, how often } \\
\text { do the following things occur in this country's elections? } 1 \text {. Votes are } \\
\text { counted fairly; } 2 \text {. Opposition candidates are prevented from running; } 3 \text {. } \\
\text { TV news favors the governing party; } 4 \text {. Voters are bribed; } 5 \text {. Journalists } \\
\text { provide fair coverage of elections; } 6 \text {. Election officials are fair; } 7 \text {. Rich } \\
\text { people buy elections; } 8 \text {. Voters are threatened with violence at the } \\
\text { polls; } 9 \text {. Voters are offered a genuine choice at the ballot box." }\end{array}$ \\
\hline $\begin{array}{l}\text { Comparative Study of } \\
\text { Electoral Systems } \\
\text { (CSES) Module I }\end{array}$ & & $\begin{array}{l}1996- \\
2002\end{array}$ & 30 & 30 & $\begin{array}{l}\text { National election } \\
\text { surveys of the general } \\
\text { electorate }\end{array}$ & $\begin{array}{l}\text { Public perceptions of the fairness of elections, on a 5-point scale, } \\
\text { monitored by the question: "In some countries, people believe their } \\
\text { elections are conducted fairly. In other countries, people believe that } \\
\text { their elections are conducted unfairly. Thinking of the last election in } \\
\text { [country], where would you place it on this scale of one to five where } \\
\text { ONE means that the last election was conducted fairly and FIVE means } \\
\text { that the last election was conducted unfairly?" }\end{array}$ \\
\hline $\begin{array}{l}\text { Gallup International } \\
\text { Voice of the People } \\
\text { Survey }\end{array}$ & & $\begin{array}{l}2005- \\
2007\end{array}$ & 65 & - & $\begin{array}{l}\text { National surveys of } \\
\text { the adult population }\end{array}$ & $\begin{array}{l}\text { "Do you feel that elections in your country are free and fair?" Coded: } \\
\text { Yes/No } \\
\text { "Would you say that your country is governed by the will of the people? } \\
\text { Coded: Yes/No }\end{array}$ \\
\hline Gallup World Poll & & 2007- & 120 & - & $\begin{array}{l}\text { National surveys of the } \\
\text { adult population }\end{array}$ & $\begin{array}{l}\text { "In [country], do you have confidence in each of the following, or not? } \\
\text { How about...Honesty of elections?" Coded: Yes/No }\end{array}$ \\
\hline IFES national surveys & & Various & & & $\begin{array}{l}\text { National surveys of the } \\
\text { adult population }\end{array}$ & Various measures about the experience and perception of elections \\
\hline
\end{tabular}


Table 2: Expert indices monitoring electoral integrity in cross-national projects

\begin{tabular}{|c|c|c|c|c|c|c|}
\hline Project & PI & Period & $\begin{array}{c}\mathbf{N} . \\
\text { nations }\end{array}$ & $\begin{array}{c}\mathbf{N} . \\
\text { elections }\end{array}$ & Data sources & Core concept and Measures \\
\hline $\begin{array}{l}\text { National Elections } \\
\text { across Democracy } \\
\text { and Autocracy } \\
\text { (NELDA) }\end{array}$ & $\begin{array}{l}\text { Susan Hyde and } \\
\text { Nikolay Marinov } \\
\text { (Yale University) }\end{array}$ & $\begin{array}{l}1945- \\
2010\end{array}$ & 162 & 2,948 & $\begin{array}{l}\text { Various including news media } \\
\text { archives, election data } \\
\text { handbooks, and online } \\
\text { election guides. }\end{array}$ & $\begin{array}{l}\text { Measures electoral competition in national presidential and legislative contests, } \\
\text { classified by: (i) Was opposition allowed? (ii) Was more than one party legal? And (iii) } \\
\text { Was there a choice of candidates on the ballot? }\end{array}$ \\
\hline $\begin{array}{l}\text { Quality of Elections } \\
\text { Data (QED) }\end{array}$ & $\begin{array}{l}\text { Judith Kelley } \\
\text { (Duke University) }\end{array}$ & $\begin{array}{l}1977- \\
2004\end{array}$ & 172 & 1206 & $\begin{array}{l}\text { US State Department Annual } \\
\text { Country Reports on Human } \\
\text { Rights Practices }\end{array}$ & $\begin{array}{l}\text { The quality of national legislative and presidential elections, where quality is } \\
\text { summarized as Acceptable (0) Ambiguous (1), and Unacceptable (2). }\end{array}$ \\
\hline $\begin{array}{l}\text { Index of Electoral } \\
\text { Malpractice (IEM) }\end{array}$ & $\begin{array}{l}\text { Sarah Birch } \\
\text { (Essex } \\
\text { University) }\end{array}$ & $\begin{array}{l}1995- \\
2007\end{array}$ & 61 & 161 & $\begin{array}{l}\text { Observer mission reports by } \\
\text { the EU, OAS and OSCE }\end{array}$ & $\begin{array}{l}\text { Electoral malpractice, defined as "the manipulation of electoral processes and } \\
\text { outcomes so as to substitute personal or partisan benefit for the public interest", as } \\
\text { measured with } 15 \text { items and collapsed into a } 1-5 \text { summary scale according to the (i) } \\
\text { legal framework, (ii) campaign practices, and (iii) electoral administration. }\end{array}$ \\
\hline $\begin{array}{l}\text { Electoral } \\
\text { Democracy index }\end{array}$ & Freedom House & $\begin{array}{l}1989- \\
2011\end{array}$ & 195 & - & $\begin{array}{l}\text { Freedom House expert } \\
\text { assessments of political rights }\end{array}$ & $\begin{array}{l}\text { Electoral democracy: Country are rated in a binary classification as an 'electoral } \\
\text { democracy' if they score in total } 7 \text { points or more (out of a possible 12) for the three } \\
\text { political rights subcategory questions on electoral process: } \\
\text { 1. Is the head of government or other chief national authority elected through free } \\
\text { and fair elections? 2. Are the national legislative representatives elected through } \\
\text { free and fair elections? } 3 \text {. Are the electoral laws and framework fair? } \\
\text { Countries also need to score as a total of } 20 \text { points or more (out of a possible 40) for } \\
\text { all ten political rights questions. }\end{array}$ \\
\hline $\begin{array}{l}\text { The CIRI Human } \\
\text { Rights Project }\end{array}$ & $\begin{array}{l}\text { David L. } \\
\text { Cingranelli and } \\
\text { David L. Richards }\end{array}$ & $\begin{array}{l}1981- \\
2010\end{array}$ & 195 & & $\begin{array}{l}\text { United States Department of } \\
\text { State's Country Reports on } \\
\text { Human Rights Practices and } \\
\text { Amnesty International }\end{array}$ & $\begin{array}{l}\text { [ELECSD] Electoral Self-Determination This variable indicates how far citizens enjoy } \\
\text { freedom of political choice and the legal right and ability in practice to change the } \\
\text { laws and officials that govern them through free and fair elections (the right to self- } \\
\text { determination). Limited (0): the right to self-determination through free and fair } \\
\text { elections did not exist in law or practice. Moderate (1): citizens had the legal right to } \\
\text { self-determination, but in practice there were some limitations. High (2): citizens } \\
\text { had the right to self-determination through free and fair elections in both law and } \\
\text { practice. }\end{array}$ \\
\hline
\end{tabular}




\section{Table 3: Electoral context and background in the selected cases}

\begin{tabular}{|c|c|c|c|c|}
\hline Country & $\begin{array}{l}\text { Month/Year of } \\
\text { WVS survey }\end{array}$ & $\begin{array}{l}\text { Year /type of previous } \\
\text { national election }\end{array}$ & $\begin{array}{l}\text { Level of liberal } \\
\text { democracy, } \\
2011\end{array}$ & Notes about election \\
\hline Uruguay & Oct-Nov 2011 & $\begin{array}{l}\text { Parliamentary and } \\
\text { Presidential elections, } \\
\text { Oct-Nov } 2009\end{array}$ & 100 & $\begin{array}{l}\text { In the second round run-off, President José Mujica, from the center-left Frente Amplio coalition, was } \\
\text { returned with } 53 \% \text { of the vote. }\end{array}$ \\
\hline Estonia & 2011 & $\begin{array}{l}\text { Parliamentary elections, } \\
\text { March } 2011\end{array}$ & 93 & $\begin{array}{l}\text { The ruling coalition of Prime Minister Andrus Ansip returned to power. In a notable innovation, nearly } 25 \\
\text { percent of voters cast their ballot online. }\end{array}$ \\
\hline Ghana & Jan-Feb 2012 & $\begin{array}{l}\text { Presidential and } \\
\text { Parliamentary elections } \\
\text { Dec } 2008\end{array}$ & 78 & $\begin{array}{l}\text { Observers celebrated Ghana's peaceful transfer of power after an extremely close run-off election. } \\
\text { Opposition candidate John Atta Mills defeated the ruling party's Nana Akufo-Addo by less than one half of a } \\
\text { percentage point of the vote. Some problems with the distribution of ballots were found in the rural Tain } \\
\text { constituency, however, which forced election officials to postpone voting there. The main opposition party } \\
\text { also challenged some results in the courts. }\end{array}$ \\
\hline Ukraine & 2011 & $\begin{array}{l}\text { Presidential Jan-Feb } \\
2010\end{array}$ & 57 & $\begin{array}{l}\text { The OSCE observer mission reported that the contests largely met international standards of democratic } \\
\text { elections, the process was transparent, and voters were offered a genuine choice of candidates, although } \\
\text { the legal framework was deficient and unsubstantiated allegations of electoral fraud negatively affected the } \\
\text { election atmosphere and voter confidence in the process. }{ }^{48} \text { The opposition leader, Tymoshenko, alleged } \\
\text { "large-scale fraud" in the country's first Presidential vote since the } 2004 \text { Orange Revolution. The coalition of } \\
\text { Western-leaning political factions in Ukraine's Parliament disintegrated. }\end{array}$ \\
\hline Nigeria & Jan-Feb 2012 & $\begin{array}{l}\text { Presidential and } \\
\text { parliamentary, April } \\
2011\end{array}$ & 57 & $\begin{array}{l}\text { President Goodluck Jonathan defeated Muhammadu Buhari to secure his first full term as the country's } \\
\text { president. The elections, which African Union international observers deemed credible and largely } \\
\text { successful, despite some minor administrative problems, triggered post-election sectarian violence } \\
\text { between Muslims and Christian communities in several northern cities. }\end{array}$ \\
\hline Kazakhstan & Nov-Dec 2011 & $\begin{array}{l}\text { Presidential election } \\
\quad \text { April } 2011\end{array}$ & 36 & $\begin{array}{l}\text { In } 2011 \text { President Nursultan Nazarbayev was reelected in a contest which the Organisation for Security and } \\
\text { Co-operation in Europe (OSCE) observer mission reported was in a non-competitive environment, given the } \\
\text { absence of opposition candidates and excessive restrictions on the right to be elected, freedom of } \\
\text { assembly, and freedom of expression, although technically well-administered. Kazakhstan's Central Election } \\
\text { Commission claimed Nazarbayev won } 95.5 \text { percent of the vote, with a turnout of } 89.5 \% .{ }^{50}\end{array}$ \\
\hline Zimbabwe & Jan 2012 & $\begin{array}{l}\text { Presidential and } \\
\text { parliamentary elections, } \\
\text { March-June } 2008\end{array}$ & 36 & $\begin{array}{l}\text { During the first round presidential elections in March 2008, the opposition leader, Morgan Tsvangirai (MDC) } \\
\text { gained more votes than President Robert Mugabe (ZANU-PF), although officials said that no candidate } \\
\text { achieved the } 50 \% \text { required for victory. A second round run-off election was held in June, but Mr Tsvangirai } \\
\text { subsequently withdrew following numerous reports of systematic attacks against MDC activists, including } \\
\text { killings and abductions. Citizens were coerced to vote in the one-candidate second ballot. The Secretary } \\
\text { General of the UN criticized the violence and intimidation surrounding the elections. }\end{array}$ \\
\hline Kyrgyzstan & 2011 & Presidential, Oct 2011 & 36 & $\begin{array}{l}\text { The OSCE report noted that there were problems in the integrity of voting, counting and tabulation with } \\
\text { cases of ballot box stuffing, multiple and family voting, vote-buying, and bussing of voters. }{ }^{51}\end{array}$ \\
\hline
\end{tabular}

Note: The level of liberal democracy is measured using the Freedom House standardized 100-point score based on political rights and civil liberties. 
Table 4: Factor analysis of survey items

\begin{tabular}{lcc} 
How often in country's elections...: & \multicolumn{2}{c}{ Component } \\
\cline { 2 - 3 } & $\begin{array}{r}\text { Electoral } \\
\text { malpractice }\end{array}$ & $\begin{array}{c}\text { Electoral } \\
\text { integrity }\end{array}$ \\
\hline Voters are bribed & .801 & .788 \\
Rich people buy elections & .691 \\
Voters are threatened with violence at the polls & .620 \\
TV news favors the governing party & .505 & .763 \\
Opposition candidates are prevented from running & & .696 \\
Election officials are fair & & .692 \\
Votes are counted fairly & & .665 \\
Journalists provide fair coverage of elections & & \\
Voters are offered a genuine choice in the elections & & \\
\hline
\end{tabular}

Notes: Extraction Method: Principal Component Analysis. Rotation Method: Varimax with Kaiser Normalization.

Source: World Values Survey $6^{\text {th }}$ wave $2010-2012$, 8 nations 
Table 5: Perceptions of electoral integrity and malpractice

\begin{tabular}{|c|c|c|c|c|c|c|c|c|c|c|c|}
\hline \multirow[b]{2}{*}{$\begin{array}{l}\text { Country } \\
\text { Code }\end{array}$} & \multicolumn{4}{|c|}{ Electoral integrity } & \multicolumn{5}{|c|}{ Electoral malpractice } & \multicolumn{2}{|c|}{ Summary scales } \\
\hline & $\begin{array}{c}\text { Votes are } \\
\text { counted } \\
\text { fairly }\end{array}$ & $\begin{array}{l}\text { Election } \\
\text { officials } \\
\text { are fair }\end{array}$ & $\begin{array}{l}\text { Voters } \\
\text { are } \\
\text { offered a } \\
\text { genuine } \\
\text { choice in } \\
\text { the } \\
\text { elections }\end{array}$ & $\begin{array}{l}\text { Journalists } \\
\text { provide } \\
\text { fair } \\
\text { coverage } \\
\text { of } \\
\text { elections }\end{array}$ & $\begin{array}{l}\text { Opposition } \\
\text { candidates } \\
\text { are } \\
\text { prevented } \\
\text { from } \\
\text { running }\end{array}$ & $\begin{array}{l}\text { TV news } \\
\text { favors the } \\
\text { governing } \\
\text { party }\end{array}$ & $\begin{array}{c}\text { Voters } \\
\text { are bribed }\end{array}$ & $\begin{array}{c}\text { Rich } \\
\text { people } \\
\text { buy } \\
\text { elections }\end{array}$ & $\begin{array}{c}\text { Voters are } \\
\text { threatened } \\
\text { with } \\
\text { violence at } \\
\text { the polls }\end{array}$ & Integrity & Malpractice \\
\hline Uruguay & $91 \%$ & $81 \%$ & $66 \%$ & $73 \%$ & $62 \%$ & $41 \%$ & $15 \%$ & $24 \%$ & $4 \%$ & $78 \%$ & $29 \%$ \\
\hline Estonia & $81 \%$ & $71 \%$ & $78 \%$ & $62 \%$ & $44 \%$ & $61 \%$ & $41 \%$ & $35 \%$ & $5 \%$ & $73 \%$ & $37 \%$ \\
\hline Ghana & $61 \%$ & $64 \%$ & $72 \%$ & $65 \%$ & $23 \%$ & $47 \%$ & $67 \%$ & $60 \%$ & $49 \%$ & $66 \%$ & $49 \%$ \\
\hline Kazakhstan & $62 \%$ & $47 \%$ & $63 \%$ & $60 \%$ & $31 \%$ & $61 \%$ & $29 \%$ & $39 \%$ & $10 \%$ & $58 \%$ & $34 \%$ \\
\hline Nigeria & $54 \%$ & $49 \%$ & $53 \%$ & $62 \%$ & $53 \%$ & $65 \%$ & $72 \%$ & $70 \%$ & $66 \%$ & $55 \%$ & $65 \%$ \\
\hline Zimbabwe & $52 \%$ & $53 \%$ & $54 \%$ & $47 \%$ & $38 \%$ & $68 \%$ & $47 \%$ & $52 \%$ & $54 \%$ & $51 \%$ & $52 \%$ \\
\hline Kyrgyzstan & $53 \%$ & $34 \%$ & $61 \%$ & $56 \%$ & $56 \%$ & $70 \%$ & $68 \%$ & $63 \%$ & $36 \%$ & $51 \%$ & $59 \%$ \\
\hline Ukraine & $38 \%$ & $25 \%$ & $47 \%$ & $56 \%$ & $59 \%$ & $72 \%$ & $71 \%$ & $79 \%$ & $19 \%$ & $42 \%$ & $60 \%$ \\
\hline Total & $60 \%$ & $52 \%$ & $62 \%$ & $60 \%$ & $45 \%$ & $62 \%$ & $55 \%$ & $56 \%$ & $34 \%$ & $59 \%$ & $50 \%$ \\
\hline
\end{tabular}

Notes: Q: "In your view, how often do the following things occur in this country's elections?" The above gives the proportion in each nation responding 'Very often' and 'fairly often'. The electoral integrity and electoral malpractice scales provide a mean score across the items.

Source: World Values Survey $6^{\text {th }}$ wave $2010-2012$, 8 nations 
Table 6: Mass and elite evaluations of electoral integrity and malpractice

\begin{tabular}{|c|c|c|c|c|c|c|c|}
\hline \multirow[b]{2}{*}{ Measure } & \multicolumn{2}{|c|}{ Mass perceptions } & \multicolumn{5}{|c|}{ Expert indices } \\
\hline & $\begin{array}{l}\text { Electoral } \\
\text { Integrity }\end{array}$ & $\begin{array}{c}\text { Electoral } \\
\text { malpractice }\end{array}$ & $\begin{array}{l}\text { Electoral } \\
\text { integrity }\end{array}$ & $\begin{array}{l}\text { Quality of } \\
\text { Elections }\end{array}$ & $\begin{array}{c}\text { Index of } \\
\text { Electoral } \\
\text { Malpractice }\end{array}$ & $\begin{array}{c}\text { Self- } \\
\text { determination } \\
\text { rights }\end{array}$ & $\begin{array}{c}\text { Electoral } \\
\text { democracy }\end{array}$ \\
\hline $\begin{array}{l}\text { Data Source and } \\
\text { period }\end{array}$ & $\begin{array}{c}\text { WVS } \\
2011-12\end{array}$ & $\begin{array}{c}\text { WVS } \\
2011-12\end{array}$ & $\begin{array}{c}\text { NELDA } \\
\text { Hyde and } \\
\text { Marivov } \\
2005-2010\end{array}$ & $\begin{array}{c}\text { QED } \\
\text { Kelley } \\
1997-2004\end{array}$ & $\begin{array}{l}\text { IEM } \\
\text { Birch }\end{array}$ & $\begin{array}{c}\text { CIRI, } \\
2005-2010\end{array}$ & $\begin{array}{l}\mathrm{FH}, \\
2010\end{array}$ \\
\hline Scales & 100pts & 100pts & 100pts & 100pts & 100pts & $0-2$ & $0 / 1$ \\
\hline Uruguay & 78 & 29 & 100 & 96 & $\mathrm{~N} / \mathrm{a}$ & 1.04 & 1 \\
\hline Estonia & 73 & 37 & 100 & 97 & 33 & 1.67 & 1 \\
\hline Ghana & 66 & 49 & 85 & 80 & $\mathrm{~N} / \mathrm{a}$ & 1.33 & 1 \\
\hline Kazakhstan & 58 & 34 & 12 & 4 & 82 & .17 & 0 \\
\hline Nigeria & 55 & 65 & 50 & 31 & $\mathrm{~N} / \mathrm{a}$ & .33 & 0 \\
\hline Zimbabwe & 51 & 52 & 20 & 34 & 77 & .0 & 0 \\
\hline Kyrgyzstan & 51 & 59 & 40 & 0 & 77 & .67 & 0 \\
\hline Ukraine & 42 & 60 & 68 & 51 & 71 & 1.0 & 1 \\
\hline
\end{tabular}

Notes: See Tables 1 and 2 for the sources of these indices and the technical appendix for details about their construction. N/a Not available 
Table 7: Correlations among mass and elite indicators of electoral integrity and malpractice

\section{Correlations}

\begin{tabular}{|c|c|c|c|c|c|c|}
\hline & $\begin{array}{c}\text { Perceptions } \\
\text { of electoral } \\
\text { integrity scale }\end{array}$ & $\begin{array}{l}\text { Perceptions } \\
\text { of electoral } \\
\text { malpractice } \\
\text { scale (WVS) }\end{array}$ & Nelda & QED & IEM & CIRI \\
\hline $\begin{array}{l}\text { Perceptions of electoral } \\
\text { malpractice scale (WVS) }\end{array}$ & $\begin{array}{r}-.778 \\
.023 \\
8\end{array}$ & & & & & \\
\hline Nelda & $\begin{array}{r}.657 \\
.077 \\
8\end{array}$ & $\begin{array}{r}-.297 \\
.475 \\
8\end{array}$ & & & & \\
\hline QED & $\begin{array}{r}.721 \\
.044 \\
8\end{array}$ & $\begin{array}{r}-.454 \\
.258 \\
8\end{array}$ & $\begin{array}{r}.914 \\
.001 \\
8\end{array}$ & & & \\
\hline IEM & $\begin{array}{r}-.758 \\
.138 \\
5\end{array}$ & $\begin{array}{r}.369 \\
.541 \\
5\end{array}$ & $\begin{array}{r}-.895 \\
.040 \\
5\end{array}$ & $\begin{array}{r}-.912 \\
.031 \\
5\end{array}$ & & \\
\hline CIRI & $\begin{array}{r}.456 \\
.256 \\
8\end{array}$ & $\begin{array}{r}-.268 \\
.520 \\
8\end{array}$ & $\begin{array}{r}.803 \\
.016 \\
8\end{array}$ & $\begin{array}{r}.660 \\
.075 \\
8\end{array}$ & $\begin{array}{r}-.869 \\
.056 \\
5\end{array}$ & \\
\hline $\mathrm{FH}$ & $\begin{array}{r}.482 \\
.226 \\
8\end{array}$ & $\begin{array}{r}-.350 \\
.395 \\
8\end{array}$ & $\begin{array}{r}.897 \\
.003 \\
8\end{array}$ & $\begin{array}{r}.882 \\
.004 \\
8\end{array}$ & $\begin{array}{r}-.732 \\
.160 \\
5\end{array}$ & $\begin{array}{r}.756 \\
.030 \\
8\end{array}$ \\
\hline
\end{tabular}

Note: For the indices, see Tables 1 and 2 and the technical appendix for details about their construction. The figures represent the simple Pearson correlations, the statistical significance, and the number of national cases for comparison. 
Figure 1: The WVS survey items measuring components in the cycle of electoral integrity

\begin{tabular}{|c|c|c|}
\hline Pre-electoral period & Campaign period & Polling day and its aftermath \\
\hline $\begin{array}{c}\text { Opposition candidates are } \\
\text { prevented from running }\end{array}$ & $\begin{array}{r}\text { TV news favors the governing } \\
\text { party }\end{array}$ & $\begin{array}{c}\text { Voters are threatened with } \\
\text { violence at the polls }\end{array}$ \\
\hline Rich people buy elections & $\begin{array}{r}\text { Journalists provide unfair } \\
\text { coverage of elections }\end{array}$ & Voters are bribed \\
\hline Election officials are unfair & $\begin{array}{r}\text { Voters are not offered a genuine } \\
\text { choice in the elections }\end{array}$ & Votes are counted unfairly \\
\hline
\end{tabular}

Source: World Values Survey $6^{\text {th }}$ wave 2010-2012 
Figure 2: Perceptions of electoral integrity and malpractice

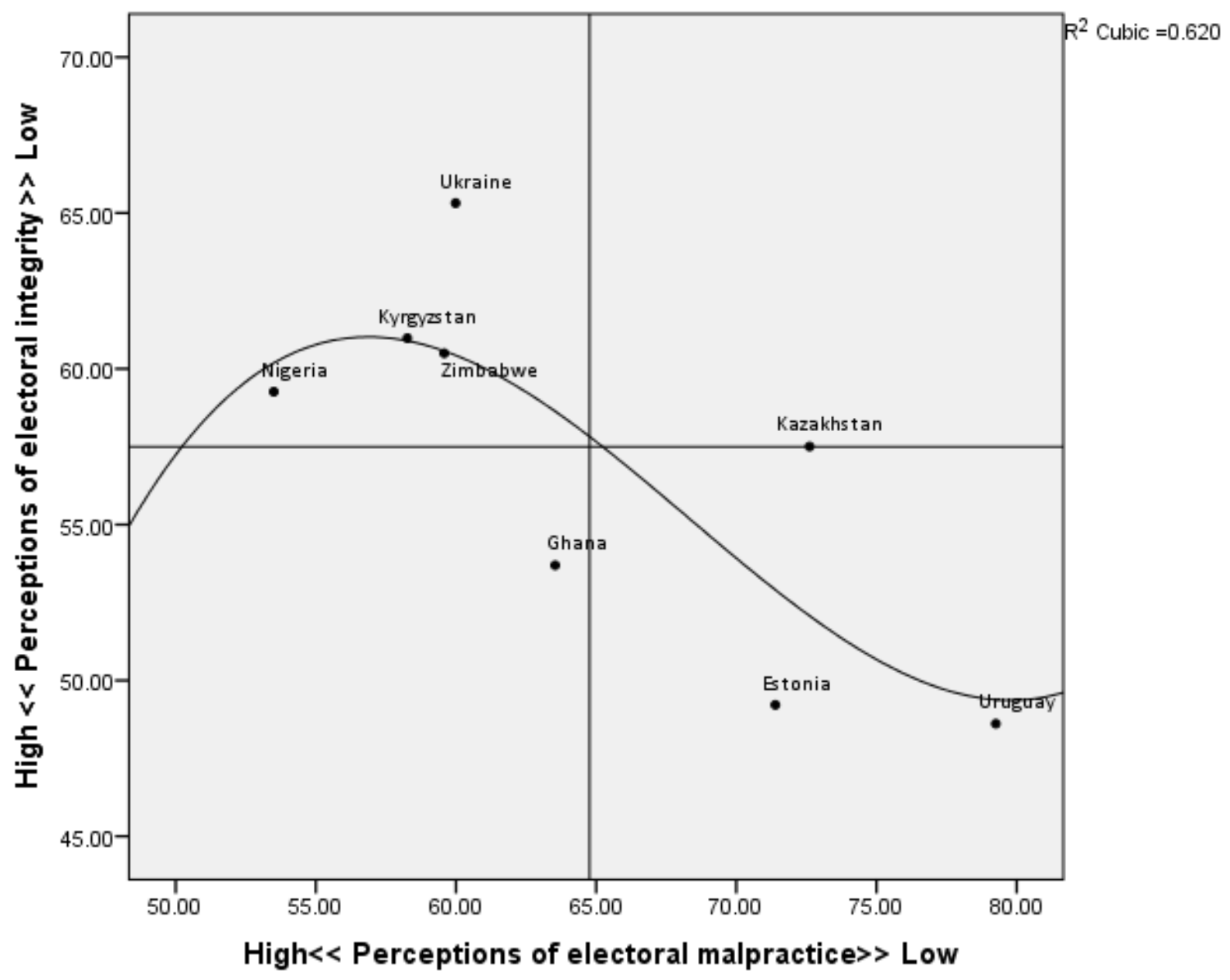

Source: World Values Survey $6^{\text {th }}$ wave $2010-2012$ 
Technical appendix: Items and aggregation

\begin{tabular}{|c|c|}
\hline Source & Items and aggregation \\
\hline $\begin{array}{l}\text { WVS 2011- } \\
2012 \\
\text { Perception } \\
\text { of Electoral } \\
\text { Integrity } \\
\text { and } \\
\text { electoral } \\
\text { malpractice }\end{array}$ & $\begin{array}{l}\text { Electoral integrity and electoral malpractice are monitored using a 9-item battery of questions } \\
\text { where responses to each item are coded on a scale from } 1 \text { 'Very often' to } 4 \text { 'Not at all often'. "In } \\
\text { your view, how often do the following things occur in this country's elections? } \\
\text { Electoral integrity: " } 1 \text {. Votes are counted fairly; } 2 \text {. Journalists provide fair coverage of elections; } 3 . \\
\text { Election officials are fair; } 4 \text {. Voters are offered a genuine choice at the ballot box." } \\
\text { Electoral malpractice: "1. Opposition candidates are prevented from running; } 2 \text {. TV news favors the } \\
\text { governing party; } 3 \text {. Voters are bribed; } 4 \text {. Rich people buy elections; } 5 \text {. Voters are threatened with } \\
\text { violence at the polls;" } \\
\text { Items are aggregated for each scale and then each score is standardized to } 100 \text { points. }\end{array}$ \\
\hline $\begin{array}{l}\text { Nelda } \\
\text { Electoral } \\
\text { Integrity } \\
2005-2010\end{array}$ & $\begin{array}{l}\text { Electoral integrity was measured in the Nelda dataset using four items: nelda11 'Before elections, } \\
\text { are there significant concerns that elections will not be free and fair?', nelda13 'Were opposition } \\
\text { leaders prevented from running', nelda15 'Is there evidence that the government harassed the } \\
\text { opposition?' and, nelda16 'In the run-up to the election, were there allegations of media bias in } \\
\text { favor of the incumbent'. These items were selected as a consistent scale on the basis of Principal } \\
\text { Component Factor Analysis with Varimax rotation. The four items were combined and then the } \\
\text { score was reversed and standardized. }\end{array}$ \\
\hline $\begin{array}{l}\text { QED 1997- } \\
2004\end{array}$ & $\begin{array}{l}\text { Electoral integrity was measured in the QED dataset by SA1 'Overall electoral quality' combined } \\
\text { with SA2 'The extent of problems'. These items were summed and the combined scores were } \\
\text { reversed and standardized. }\end{array}$ \\
\hline $\begin{array}{l}\text { IEM 1995- } \\
2007\end{array}$ & $\begin{array}{l}\text { Electoral Malpractice was measured in the IEM dataset by combining fourteen items, each } \\
\text { measured on a 5-point scale, monitoring the Legal framework, the independence of the electoral } \\
\text { authorities, candidate contestation, voter registration, polling arrangements, voting processes, vote } \\
\text { counting, the role of observers, balanced coverage by the media, regulation of campaign resources, } \\
\text { vote buying, voter intimidation, and candidate intimidation. Missing data was replaced by mean } \\
\text { substitution to avoid dropping cases. The overall score was then standardized. }\end{array}$ \\
\hline $\begin{array}{l}\text { CIRI 2005- } \\
2010\end{array}$ & $\begin{array}{l}\text { Electoral Self-Determination in the CIRI dataset indicates how far citizens enjoy freedom of political } \\
\text { choice and the legal right and ability in practice to change the laws and officials that govern them } \\
\text { through free and fair elections (the right to self-determination). Limited (0): the right to self- } \\
\text { determination through free and fair elections did not exist in law or practice. Moderate (1): citizens } \\
\text { had the legal right to self-determination, but in practice there were some limitations. High (2): } \\
\text { citizens had the right to self-determination through free and fair elections in both law and practice. } \\
\text { The variable was not recoded from the original. }\end{array}$ \\
\hline FH 2010 & $\begin{array}{l}\text { Electoral democracy: Country are rated by Freedom House as an 'electoral democracy' if they score } \\
\text { in total } 7 \text { points or more (out of a possible 12) for the three political rights subcategory questions on } \\
\text { electoral process: } 1 \text {. Is the head of government or other chief national authority elected through } \\
\text { free and fair elections? } 2 \text {. Are the national legislative representatives elected through free and fair } \\
\text { elections? } 3 \text {. Are the electoral laws and framework fair? Countries also need to score as a total of } 20 \\
\text { points or more (out of a possible } 40 \text { ) for all ten political rights questions. The classification by FH was } \\
\text { coded as a binary variable, electoral democracy (1) or not (0). }\end{array}$ \\
\hline
\end{tabular}


Acknowledgments: The author is most grateful to International IDEA for facilitating the inclusion of the new battery of items and for supporting the $6^{\text {th }}$ Wave of the World Values Survey and to the Principle Investigator, Ronald Inglehart, for collaboration on this project. The author is also most grateful to Susan Hyde and Nicholay Marinov for sharing the advance release of the NELDA dataset 1945-2011. This study was supported by the Australian Research Council Laureate award as part of a larger research project on Challenges of Electoral Integrity.

${ }^{1}$ See Sarah Birch. 2012. Electoral Malpractice. Oxford: Oxford University Press; Susan D. Hyde and Nikolay Marinov. Codebook for National Elections across Democracy and Autocracy (NELDA) Nov $10^{\text {th }} 2011$; Judith Kelley. 2010. Quality of Elections Data Codebook. http://sites.duke.edu/kelley/data/.

${ }^{2}$ R. Michael Alvarez, Thad E. Hall and Susan Hyde. 2008. Election fraud: detecting and deterring electoral manipulation. Washington, DC: Brookings Institute; Mikhail Myagkov, Peter C. Ordeshook and Dimitri Shakin. 2009. The Forensics of Election Fraud: Russia and Ukraine. New York: Cambridge University Press; Sarah Birch. 2012. Electoral Malpractice. Oxford: Oxford University Press.

${ }^{3}$ See Staffan Lindberg. 2006. Democracy and Elections in Africa. Baltimore, MD: The Johns Hopkins University Press; Schedler, Andreas. (ed.). 2006. Electoral Authoritarianism: The Dynamics of Unfree Competition. Boulder and London: Lynne Rienner; Jason Brownlee. 2007. Authoritarianism in an Age of Democratization. New York: Cambridge University Press; Staffan Lindberg. Ed. 2009. Democratization by Elections: A New Mode of Transition. Baltimore, MD: The Johns Hopkins University Press; Steven Levitsky and Lucan A. Way. 2010. Competitive Authoritarianism: Hybrid Regimes after the Cold War, New York: Cambridge University Press.

${ }^{4}$ Eric C. Bjornlund. 2004. Beyond Free and Fair: Monitoring Elections and Building Democracy. Washington DC: Woodrow Wilson Center Press; Guy S. Goodwin-Gill. 2006. Free and Fair Elections. $2^{\text {nd }}$ Edition. Geneva: Interparliamentary Union; John Hardin Young. 2009. International Election Principles: Democracy and the Rule of Law. Chicago: American Bar Association; Susan. D. Hyde. 2011. The Pseudo-Democrat's Dilemma. Ithaca: Cornell University Press; Judith Kelley. 2012. Monitoring Democracy: When International Election Observation Works and Why it Often Fails. Princeton, NJ: Princeton University Press.

${ }^{5}$ Sarah Birch. 2008. 'Electoral institutions and popular confidence in electoral processes: a cross-national analysis.' Electoral Studies 27 (2): 305-20.

${ }^{6}$ Pippa Norris. 2011. Democratic Deficit. New York: Cambridge University Press.

7 Edward D. Mansfield and Jack Snyder. 1995. 'Democratization and the danger of war.' International Security 20 (1): 5-38; Edward D. Mansfield and Jack Snyder. 2007. Electing to Fight: Why Emerging Democracies go to War. Cambridge, MA: MIT Press; Mark R. Thompson \& Philipp Kuntz, 2009. 'More than just the final straw: Stolen elections as revolutionary triggers.' Comparative Politics 41(3):253-272.

${ }^{8}$ See, for example, the Global Commission on Elections, Democracy and Security launched by the International Institute for Electoral Assistance (International IDEA) and the Kofi Annan Foundation in March 2011.

${ }^{9}$ Jorgen Elklit and Palle Svensson. 1997. 'What makes elections free and fair?' Journal of Democracy 8 (3): 32-46.

${ }^{10}$ Karl-Heinz Nassmacher. 2009. The Funding of Party Competition: Political Finance in 25 Democracies. Nomos; Kevin Casas-Zamora. 2004. Paying for Democracy. Essex: ECPR Press; Michael Koss. 2011. The Politics of Party Funding. Oxford: Oxford University Press; Magnus Öhman and Hani Zainulbhai. 2011. Political Finance Regulation: The Global Experience. Washington, DC: IFES.

11 International Covenant on Civil and Political Rights, adopted in 1966. http://www2.ohchr.org/english/law/ccpr.htm

12 http://treaties.un.org/Pages/ViewDetails.aspx?src=TREATY\&mtdsg no=IV-4\&chapter=4\&lang=en 
13 John Hardin Young. 2009. International Election Principles: Democracy and the Rule of Law. Chicago: American Bar Association.

${ }^{14}$ OSCE. 2010. Election Observation Handbook. $6^{\text {th }}$ edition. Warsaw: OSCE/ODIHR.

${ }^{15}$ Eric C. Bjornlund, 2004. Beyond Free and Fair: Monitoring Elections and Building Democracy. Washington DC: Woodrow Wilson Center Press. See chapter 6 comparing the principles and standards issued by different international organizations.

${ }^{16}$ http://www.unodc.org/unodc/en/treaties/CAC/

${ }^{17}$ Magnus Öhman, Magnus and Hani Zainulbhai. 2011. Political Finance Regulation: The Global Experience. Washington, DC: IFES. http://www.ifes.org/files/Political_Finance_Regulation_The_Global_Experience.pdf

${ }^{18}$ Susan Stokes, Thad Dunning, Marcelo Nazareno and Valeria Brusco. 2012. Buying Votes: Distributive Politics in Democracies.

${ }^{19}$ H. F. Gosnell. 1968. Machine Politics: Chicago Model, $2^{\text {nd }}$ ed., Chicago and London: University of Chicago Press.

${ }^{20}$ Raffaele Romanelli. Ed. 1998. How did they become voters? The history of franchise in modern European representation. The Hague: Kluwer Law

${ }^{21}$ Alexander Keyssar. 2009. The Right to Vote: The Contested History of Democracy in the United States. New York: Basic Books. Revised edition.

${ }^{22}$ Marian Sawer. Ed. 2001. Elections: Full, free and Fair. Annandale, NSW: The Federation Press.

${ }^{23}$ Spencer Overton. 2006. Stealing Democracy: The New Politics of Voter Suppression. New York: Norton; Lorraine Carol Minnite. 2010. The Myth of Voter Fraud. Ithaca: Cornell University Press.

${ }^{24}$ Edward D. Mansfield and Jack Snyder. 1995. 'Democratization and the Danger of War.' International Security 20 (1): 5-38; Edward D. Mansfield and Jack Snyder. 2007. Electing to Fight: Why Emerging Democracies go to War. Cambridge, MA: MIT Press.

${ }^{25}$ See, for example, the Global Commission on Elections, Democracy and Security launched by the International Institute for Electoral Assistance (International IDEA) and the Kofi Annan Foundation in March 2011.

${ }^{26}$ See, for example, the ACE Electoral Knowledge Network http://aceproject.org/; Alvarez, R. Michael, and Thad E. Hall. 2008. 'Building secure and transparent elections through standard operating procedures.' Public Administration Review 68 (5): 828-38.

27 Susan B. Hyde. 2011. The Pseudo-Democrat's Dilemma. Ithaca: Cornell University Press; Judith Kelley. 2012. Monitoring Democracy: When International Election Observation Works and Why it Often Fails. Princeton, NJ: Princeton University Press.

28 Peter Burnell. Ed. 2010. Democracy Assistance: International Co-operation for Democratization. London: Routledge.

${ }^{29}$ UNDP Global Programme for Electoral Cycle Support

http://web.undp.org/eu/UNDP Global Programme for Electoral Cycle Support\%20.shtml

${ }^{30}$ http://aceproject.org/ero-en/topics/electoral-management/electoral\%20cycle.JPG/view

${ }^{31}$ Sarah Birch. 2012. Electoral Malpractice. Oxford: Oxford University Press

32 Andreas Schedler. 2002. 'The menu of manipulation.' Journal of Democracy 13(2): 36-50.

33 George, Alexander L. and Andrew Bennett. 2004. Case Studies and Theory Development. Cambridge, MA: The MIT Press.

${ }^{34}$ Similar issues confront the construction and use of indicators of democratization and human rights; see, for example, Geraldo L. Munck and Jay Verkuilen. 2002. 'Conceptualizing and measuring democracy: Evaluating 
alternative indices.' Comparative Political Studies 35 (1): 5-34; Todd Landman and Edzia Carvalho. 2010. Measuring Human Rights. London: Routledge; Geraldo L. Munck. 2009. Measuring Democracy: A Bridge between Scholarship and Politics. Baltimore: The Johns Hopkins Press.

${ }^{35}$ Gallup International. 2005. Voice of the People 2005: Trends in democracy.

${ }^{36}$ www.freedomhouse.org

${ }^{37}$ Naomi Chazan, Peter Lewis, Robert Mortimer, Donald Rothchild, and Steven Stedman. 1999. Politics and Society in Contemporary Africa. Lynne Rienner Publishers and London: Macmillan; Joseph Aye. 2000. Deepening Democracy in Ghana. Freedom Publications; Kwame Boafo-Arthur (Ed). 2007. Ghana: One Decade of the Liberal State. Zed Books.

${ }^{38}$ See Sarah Birch. 2012. Electoral Malpractice. Oxford: Oxford University Press; Susan D. Hyde and Nikolay Marinov. Codebook for National Elections across Democracy and Autocracy (NELDA) Nov $10^{\text {th }}$ 2011; Judith Kelley. 2010. Quality of Elections Data Codebook. http://sites.duke.edu/kellev/data/.

${ }^{39}$ Susan D. Hyde and Nikolay Marinov. Codebook for National Elections across Democracy and Autocracy (NELDA) Nov $10^{\text {th }} 2011$.

${ }^{40} \mathrm{CIRI}$ Human Rights Data Project. The Cingranelli and Richards (CIRI) dataset The Cingranelli-Richards (CIRI) Human Rights Dataset contains standards-based quantitative information on government respect for 15 internationally recognized human rights for 195 countries, annually from 1981-2010. http://ciri.binghamton.edu/

41 Judith Kelley. 2010. Quality of Elections Data Codebook. http://sites.duke.edu/kelley/data/

${ }^{42}$ www.freedomhouse.org

${ }^{43}$ Sarah Birch. 2012. Electoral Malpractice. Oxford: Oxford University Press. For the dataset and methodology, see http://www.essex.ac.uk/government/electoralmalpractice/index.htm

${ }^{44}$ Susan D. Hyde and Nikolay Marinov. Codebook for National Elections across Democracy and Autocracy (NELDA) Nov $10^{\text {th }} 2011$.

${ }^{45}$ See Adam Przeworski, Michael E. Alvarez, Jose Antonio Cheibub, and Fernando Limongi. 2000. Democracy and Development: Political Institutions and Well-Being in the World, 1950-1990. New York: Cambridge University Press.

${ }^{46}$ CIRI Human Rights Data Project. http://ciri.binghamton.edu/

${ }^{47}$ Pippa Norris. 2009. Driving Democracy. New York: Cambridge University Press.

48 OSCE/ODIHR. 2011. Ukraine Presidential Election 17 January and 7 February 2010 OSCE/ODIHR Election Observation Mission Final Report. Warsaw. http://www.osce.org/odihr/elections

${ }^{49}$ African Union. 2011. Preliminary statement of the African Union observer mission on the 2011 presidential election in Nigeria 16 April 2011

${ }^{50}$ OSCE/ODIHR. 2011. Republic Of Kazakhstan Early Presidential Election 3 April 2011 OSCE/ODIHR Election Observation Mission Final Report. Warsaw. http://www.osce.org/odihr/elections

51 OSCE/ODIHR. 2011. OSCE/ODIHR Election Observation Mission Final Report. Warsaw. http://www.osce.org/odihr/elections 